\title{
A REVISION OF COSMIOCRYPTUS IN THE COASTAL DESERT OF PERÚ AND NORTH CHILE (HYMENOPTERA: ICHNEUMONIDAE)
}

\author{
By Charles C. Porter ${ }^{1}$ \\ Department of Biological Sciences, Fordham University \\ Bronx, NY 10458
}

INTRODUCTION

Taxonomy and Relationships

Cosmiocryptus, as here defined, ranges from Ecuador to Perú, Bolivia, Brasil, Argentina, and the Neantarctic regions of Chile. Like its close relative Trachsphyrus, this genus prefers Andean (up to at least $4000 \mathrm{~m}$ ), semiarid, and temperate habitats, but also has a few specialized representatives in tropical South America below the equator and outside the Amazon Basin.

Cosmiocryptus includes at least 50 described species (Porter 1967) plus as many as 100 still undescribed representatives. My concept of Cosmiocryptus (NEW STATUS) includes most of the species placed by Townes (1969: 179-81) under Chromocryptus, with the exception of Chromocryptus itself (which I recognize as a separate genus restricted to species intimately related to Phygadeuon Planosae Fitch). It should be noted that Townes (1969: 181) tentatively synonymizes Cosmiocryptus with Trachysphyrus. However, Cosmiocryptus does not fit in Trachysphyrus, as defined either by Townes or by me, since its type species has the axillus vein "parallel to the anal margin of the hind wing" (Townes 1969: 159) and so will run in Townes key (1969: 159-65) to Chromocryptus.

Cosmiocryptus is a heterogeneous assemblage of perhaps diverse affinities. Some of its species superficially resemble Holarctic members of the related genera Itamoplex and Caenocryptus. Others may be close to the large but as yet little studied temperate Australian and Tasmanian "trachysphyroid" fauna. It is thus not possible

\footnotetext{
'Research Associate, Florida State Collection of Arthropods, Florida Department of Agriculture and Consumer Services, P.O. Box 1269, Gainesville, FL 32602 Manuscript received by the editor May 10, 1985.
} 
to give an exhaustive generic description of Cosmiocryptus but species in the Coastal Desert may be recognized by the following combination of characters: Axillus close to anal margin of hind wing; base of 1st gastric tergite without a lateral tooth; mediella moderately arched to almost straight; mandible stout with lower tooth not longer than upper; hind coxa with a strong subvertical groove externo-ventrally near base; propodeal cristae never elongately spiniform; 1st gastric tergite rarely with large and dense punctures.

\section{Ecology and Host Records}

Cosmiocryptus often are found on the branches of shrubs or trees or in herbaceous vegetation. Information about habitat preferences of many species is given under the discussion of each taxon.

The only rearing record for Cosmiocryptus in the Coastal Desert is from a species of Megalopyge (Lepidoptera: Megalopygidae).

\section{Collections}

Listed below in alphabetic order are collections which furnished material for this study and/or in which type and voucher specimens are or are to be deposited. I refer to institutional collections by the name of the city where they are located and to individual collections by the surname of the owner. Specimens of Cosmiocryptus violaceipennis, of $C$. diplatys, and of $C$. weyrauchi will be distributed to Arica, Cambridge, College Station, Gainesville, Lawrence, Porter, Townes, and Gainesville.

ARICA. Centro de Investigacíon y Capacitacíon Agricola, Departamento de Agricultura, Universidad de Tarapacá, Arica, CHILE.

CAMBRIDGE. Museum of Comparative Zoology, Harvard University, Cambridge, MASS 02138.

College Station. Department of Entomology, Texas A \& M University, College Station, TX 77843.

Gainesville. Florida State Collection of Arthropods, Bureau of Entomology, Division of Plant Industry, Florida Department of Agriculture and Consumer Services, P.O. Box 1269, 1911 SW 34th Street, Gainesville, FL 32602.

LAWRENCE. Department of Entomology, Snow Entomological Museum, The University of Kansas, Lawrence, KS 66045 
Porter. Collection of Charles C. Porter, 301 North 39th Street, McAllen, TX 78501.

Townes. American Entomological Institute, c/o Dr. Virendra Gupta, Bureau of Entomology, Division of Plant Industry, Florida Department of Agriculture and Consumer Services, P.O. Box 1269, Gainesville, FL 32602.

WASHington. Department of Entomology, U.S. National Museum, NHB 168, Washington, DC 20560

\section{Genus COSMIOCRYPTUS}

Cosmiocryptus Cameron, 1902. Trans. Amer. Ent. Soc. 28: 371. Type: Cosmiocryptus violaceipennis Cameron

Neocryptopteryx Blanchard, 1947. Commun. Zool. Mus. Hist. Nat. Montevideo 2(42): 1. Type: Neocryptopteryx orientalis Blanchard. New synonym.

\section{Key to the Coastal Desert Cosmiocryptus}

FEMALES

1. Gaster solid red or red with black staining; flagellum black with a white band; clypeus low to moderately raised, symmetrically to asymmetrically convex in profile ............

$1^{\prime}$. Gaster variously patterned with red, black, and white; flagellum not black and white; clypeus strongly raised, bluntly and asymmetrically pyramidal in profile $\ldots \ldots \ldots \ldots \ldots 7$

2. Epomia turned mesad above and enclosing a triangular area; mesoscutum shining and with much gross punctation and wrinkling along notauli and on peripheries of lateral lobes but duller and more finely punctured centrad on lobes; propodeal cristae very strongly projecting cuneate to ligulate; ventro-lateral carina absent on 1 st gastric tergite; sheathed portion of ovipositor $0.8-0.9$ as long as fore wing, gently upcurved .................. . . huascar (Porter)

2 '. Epomia not turned mesad at its upper end; mesoscutum uniformly more or less shining, without or with rather weak wrinkling along notauli and not more strongly sculptured on peripheries of lateral lobes; propodeal cristae more or less strong, moderately projecting, subligulate or subcuneate; ventro-lateral carina distinct throughout on petiole; sheathed portion of ovipositor $0.4-0.6$ as long as fore wing, straight

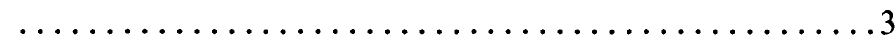


3. Apical margin of clypeus produced and with a pair of tubercles on median 0.3 ; malar space 0.9 as long as basal width of mandible; 2nd gastric tergite smooth and shining, slightly micro-reticulate, with very sparse setae ..............

8. C. weyrauchi Porter

3'. Apical margin of clypeus not tuberculate; malar space often less than 0.9 basal width of mandible; 2 nd gastric tergite with micro-reticulation often stronger and setae often denser than described above.........................4

4. First flagellomere 6.2-7.8 as long as deep at apex; temple 0.6-0.8 as long as eye in dorsal view; sheathed portion of ovipositor 0.6 as long as fore wing; both dorsal and ventral valves of ovipositor broadly and strongly flattened on tip, dorsal valve profile between notch and apex gently concave ..........

......................... 5. diplatys (Porter)

$4^{\prime}$. First flagellomere 5.0-6.0 as long as deep at apex; temple 0.4-0.5 as long as eye in dorsal view; sheathed portion of ovipositor 0.4-0.5 as long as fore wing; ovipositor valves at most moderately flattened on tip, the dorsal valve with a straight or slightly convex taper between notch and apex .........5

5. Fore tibia stout but not inflated; postpetiole 1.5 as wide apically as long from spiracle to apex; ovipositor slender with nodus very weak, tip 0.16 as high at notch as long from notch to apex; dorsal valve minutely tuberculate on tip ...........

7. C. leptaechma n. sp.

5 '. Fore tibia palpably inflated; postpetiole $1.5-2.0$ as wide apically as long from spiracle to apex; ovipositor more robust with distinct nodus, its tip $0.22-0.28$ as high at notch as long from notch to apex.......................... 6

6. First flagellomere 5.5-6.0 as long as deep at apex; mesopleuron grossly reticulate but always with a shining and discretely punctate swelling above along prepectus opposite speculum; 2nd gastric tergite with distinct finely granular microreticulation and with short setae that largely approach the length of their interspaces; ovipositor stout, moderately compressed, profile of its basal valve between nodus and apex basally straight or a little concavely flattened and then convex toward tip ......... 4. C. violaceipennis (Cameron) 
6'. First flagellomere 5.0 as long as deep at apex; mesopleuron strongly, but not grossly, reticulately wrinkled, without a raised or shiny area opposite speculum along prepectal carina; 2nd gastric tergite finely reticulate but with setae much shorter than their interspaces; ovipositor strongly compressed, with a high nodus, dorsal valve directly tapering between notch and apex.............6. C. aricae n. sp.

7. Speculum uniformly punctate, mesopleuron otherwise with fine reticulate wrinkling; 2 nd abscissa of radius 0.5 as long as 1 st intercubitus; 2 nd recurrent straight or slightly reclivous, palpably outcurved above; mediella gently arched; apical transcarina of propodeum fine and sharp, looped far forward medially; postpetiole 1.1-1.3 as wide apically as long from spiracle to apex; 2nd gastric tergite dully shining with uniform delicate microreticulation; ovipositor slender and compressed, tip $0.22-0.23$ as high at notch as long from notch to apex; wings hyaline; antennae blackish ............. 1. C. occidens n. sp.

$7^{\prime}$. Speculum largely smooth and shining, rest of mesopleuron grossly sculptured; 2nd abscissa of radius 0.8 as long as 1 st intercubitus; 2nd recurrent gently inclivous, almost straight, not outcurved above; apical trans-carina of propodeum obsolete; postpetiole 1.7 as wide apically as long from spiracle to apex; 2nd gastric tergite smooth and conspicuously shining with faint micro-reticulation that practically fades out toward apex; ovipositor robust, tip 0.30 as high at notch as long from notch to apex; antennae reddish; wings black 3. C. leucetrum n. sp.

\section{MALES}

(Males of Cosmiocryptus leucetrum, C. aricae and of C. leptaechma unknown).

1. Mediella rather strongly arched; 2nd recurrent palpably outcurved above; temple $0.5-0.6$ as long as eye in dorsal view; postpetiole $0.5-0.9$ as wide apically as long from spiracle to apex; 2nd gastric tergite dully shining with uniform microreticulation; gaster black, red, and white $\ldots \ldots \ldots \ldots \ldots \ldots$ 
1'. Mediella straight; 2 nd recurrent not outcurved on upper 0.5 ; temple $0.6-1.0$ as long as eye in dorsal view; postpetiole $0.9-1.4$ as wide apically as long from spiracle to apex; 2 nd gastric tergite smooth and shining with variably developed delicate microreticulation, solid red or red and blackish...2

2. Flagellum without white band; propodeal cristae large, strongly projecting ligulate or subligulate; epomia bent mesad above, where it delimits an appressed triangular area; malar space 0.9 as long as basal width of mandible...............

2. C. huascar (Porter)

2 '. Flagellum marked with white; propodeal cristae well developed, broadly subligulate, not so prominently projecting as in the previous species; epomia strong but not modified at its upper end; malar space $0.6-0.8$ as long as basal width of mandible

.....................................

3. Median 0.3 of clypeus produced and with a pair of blunt tubercles; 1 st flagellomere 2.6-3.0 as long as deep at apex; in most specimens setae of 2 nd gastric tergite average palpably shorter than the length of their interspaces ...............

8. C. weyrauchi (Porter)

$3^{\prime}$. Clypeal apex etuberculate; 1st flagellomere $3.7-5.0$ as long as deep at apex; setae of 2 nd gastric tergite consistently exceed the length of their interspaces .................. 4

4. Mesoscutum strongly shining with abundant but delicate punctation and wrinkling; flagellum with only the 3rd tyloid (counting from base) unusually broad, the rest ovoid to linear.....

5. C. diplatys (Porter)

4'. Mesoscutum rather dully shining, with abundant dense punctures and wrinkles; flagellum with at least 2 nd and usually 1 st-3rd tyloids broadly oval

\section{C. violaceipennis (Cameron)}

\section{Cosmiocryptus occidens Porter, new species}

(Fig. 1)

FEMALE. Color: scape dull reddish brown, antenna otherwise nearly black; head and mesosoma black with brown staining on mandibles, a dull to pure white spot on base of mandible, and a brownish white to mostly white area on clypeus, as well as with the 


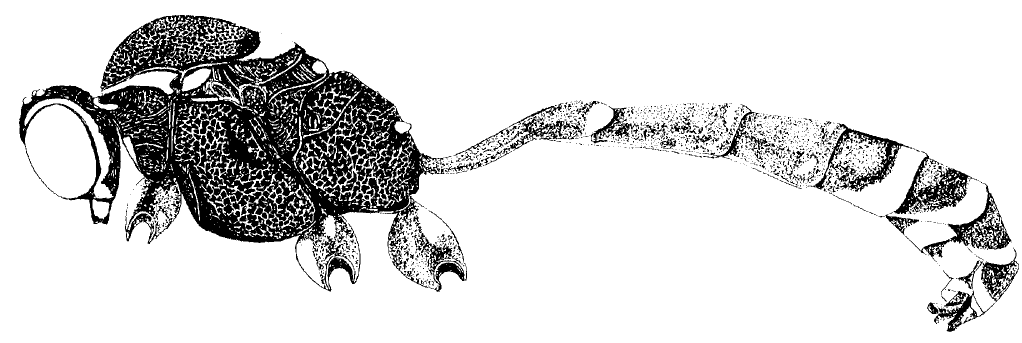

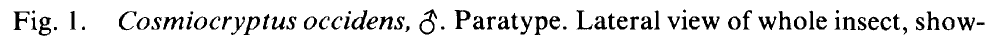
ing color pattern and habitus.

following mostly pure white ornamentation: orbital ring, broken only at bottom of eye; blotch in malar space (sometimes merging with hind orbital band); broad band on pronotal collar; sometimes blotch on anterior-ventral margin of pronotum near mid-height; broad line on dorsal margin of pronotum near mid-height; broad line on dorsal margin of pronotum, interrupted only in front between bases of notauli; about outer 0.5 to almost all of tegula; sometimes small triangular spot on each anterior corner of scutellum; sometimes pair of tiny dots on postscutellum; tips of propodeal cristae; and a tiny dot on subalarum; 1st gastric tergite red with some faint dusky staining that becomes darker near base; 2nd tergite dull red with slight dusky staining; 3 rd tergite dull red and more or less conspicuously dusky tinged, sometimes grading into blackish on apical 0.3 and throughout laterad; 4 th tergite black with some reddish basally or sometimes mostly red and always with a very broad white apical band which becomes even broader laterad; 5th and 6th tergites black with a very broad white apical band; succeeding tergites black with extensive, irregular white markings; legs red, duller on tibiae and tarsi, sometimes with a tiny white dot near base on hind coxa; wings hyaline with fore wing faintly brownish tinged.

Length of fore wing: 7.0-7.1 mm. First flagellomere: $6.8-7.7$ as long as deep at apex. Clypeus: rather high, strongly blunt-pyramidal in profile; apical margin very weakly convex. Malar space: 1.0 as long as basal width of mandible. Temple: $0.23-0.33$ as long as eye in dorsal view; precipitously receding and slightly rounded off. Cephalic carinae. occipital carina sharp but scarcely raised; hypostomal carina only slightly higher than occipital. Fore tibia: rather 
slender, with a weak swelling near basal 0.3. Pronotum: dorsal margin weakly swollen; submarginal groove narrow and obsolete; epomia sharp and strong in scrobe, prolonged briefly below, unmodified above. Mesoscutum: notauli narrow, shallow but conspicuous, extending about 0.7 the length of mesoscutum; surface at most dully shining, finely but strongly reticulo-rugose to reticulo-punctate on central lobe and on an extensive area behind end of notauli, more coarsely and transversely wrinkled immediately along notauli, sometimes on lateral lobes a little more shining in comparison to rest of mesoscutum and with fine but sharp puncto-reticulation that includes many almost discrete punctures. Mesopleuron: speculum slightly differentiated, more shining than rest of surface, with uniform and comparatively coarse punctation; surface otherwise with uniform finely reticulate wrinkling. Wing venation: radial cell 3.3-3.5 as long as wide; areolet large; intercubiti strongly convergent above; 2nd abscissa of radius 0.5 as long as 1st intercubitus; 2nd recurrent straight or a little reclivous below, definitely outcurved above; discocubitus broadly angled, with a long ramellus; mediella gently arched; nervellus broken well below middle, upper part 3.5 as long as lower. Propodeum: short and high, faces subequal, basal sloping, apical discrete and nearly vertical; spiracle 2.0 as long as wide; area basalis weakly defined; basal trans-carina strong and sharp throughout, much raised medially; apical trans-carina fine and sharp, sometimes weakened laterad, medially thrust far forward; cristae of moderate size, briefly ligulate, projecting; median longitudinal carina delimiting a broadly hexagonal areola; lateral longitudinal carina scarcely suggested; surface dully shining, basad of basal trans-carina puncto-reticulate, rugose between transcarinae, a little more finely reticulate on apical face. First gastric tergite: $1.1-1.3$ as wide apically as long from spiracle to apex; ventro-lateral carina fine and sharp throughout; dorso-lateral carina very sharp on postpetiole but gradually weakening basad on petiole; dorsal carinae prominent but blunt and enclosing a low median elevation toward apex of petiole and on base of postpetiole; surface of postpetiole dully shining except more polished on apical 0.3 and with delicate micro-reticulation that fades out near apex. Second gastric tergite: dully shining with uniform delicate microreticulation and a few minute, obscure punctures emitting short, widely scattered setae. Ovipositor: sheathed portion 0.6 as long as fore wing; 
only slightly upcurved, slender, compressed; nodus only gently raised, with a minute notch; ventral valve with fine, well spaced oblique ridges on tip, tip 0.23 as high at notch as long from notch to apex.

MALE. Color: differs from female as follows: white spot beneath on scape; white markings on head broader; tegula wholly white; often most of scutellum and postscutellum white; almost percurrent white line on subalarum; 1st gastric tergite with a broad white band on apex; 2nd and 3rd tergites with laterally abbreviated white apical bands, with that of 3rd tergite comparatively weak or irregular (or sometimes all tergites with complete white apical bands); 5th tergite red on basal $0.4 ; 7$ th tergite black with a broad white apical band; clasper brownish with a large black spot; fore and mid tarsi dusky, hind tarsus blackish; hind tibia tinged with dusky above, especially toward apex; fore and mid coxae with a black area dorsally that is bounded anteriorly by a large white area and posteriorly by a smaller white area; hind coxa with a large white blotch dorsally on basal 0.5 and sometimes with a little brownish staining apically; fore and mid trochanters white with a broad and nearly percurrent black stripe above; mid trochantellus red as in female but with considerable blackish above.

Length of fore wing: $5.3-7.3 \mathrm{~mm}$. First flagellomere: $4.4-4.5$ as long as deep at apex. Malar space; 0.9 as long as basal width of mandible. Temple: $0.5-0.6$ as long as eye in dorsal view. Mesoscutum: notauli sometimes traceable but faint, sometimes as strong as in female. Mesopleuron: speculum often more polished than in female, with some smooth interspaces among the punctures. Wing venation: ramellus sometimes very short; mediella quite strongly arched, its upper part 2.4 as long as the lower part. Propodeum: basal face strongly declivous; apical face nearly vertical, well differentiated from basal face and 0.7 as long as basal face; spiracle 1.5-1.7 as long as wide; basal trans-carina sometimes becoming a little irregular laterad, but as strongly raised on meson as in female; apical trans-carina fine and gently to rather strongly curved forward on median 0.3-0.6 but weak to obsolete laterad; cristae prominent robustly cuneate; longitudinal carinae scarcely suggested. First gastric tergite: postpetiole weakly expanded apicad, $0.5-0.9$ as wide apically as long from spiracle to apex; ventro-lateral carina strong throughout, except sometimes weaker below spiracle; dorso-lateral 
carina weakly and irregularly defined; dorsal carinae absent; surface with coarser and more granular micro-reticulation than in female; setae largely surpassing the length of their interspaces, much longer and denser than in female.

TYPe Material. Holotype $:$ PERÚ, Lima Province, San Gerónimo, 5-VII-1976, C. Porter. Paratypes: 19, 30̂: PERÚ, Lima Province, Matucana, 2389 m, 28-30-VI-1974, C. Porter, L. Stange, 7-9-VII-1975, C. Porter; La Libertad Province, Samne nr. Trujillo, 1500 m, 12-17-VII-1975, C. Porter, L. Stange. Holotype in Florida State Collection of Arthropods. Paratypes in Florida State Collection of Arthropods ( $1 \hat{\delta})$, Collection of Henry K. Townes $(1 \hat{O})$, and Collection of Charles C. Porter $(1+, 1 \hat{)})$.

RELATIONSHIPS. Cosmiocryptus occidens belongs to the Rufitibia group within its genus (Porter 1967: 124-6) and is very closely related to the central Andean C. townesorum Porter (1967: 135-7). ${ }^{1}$ Probably, these 2 species are vicariants which differentiated, in the Puna and Coastal Desert respectively, while late Tertiary and Pleistocene climatic changes alternately prevented and encouraged dispersal of xerophilous biota across the highest Andean cordilleras. A similar relationship seems to obtain between the ephialtine ichneumonids Itoplectis niobe Schrottky (mostly restricted to above 2500 $\mathrm{m}$ in Perú) and Itoplectis phoenogaster Porter (a closely related Itoplectis endemic to the Coastal Desert below $2500 \mathrm{~m}$, as discussed by Porter 1979: 180-1).

Cosmiocryptus townesorum differs from $C$. occidens in lacking a white band on the female flagellum, in its absence of red markings, longer temple (0.4-0.5 as long as eye in dorsal view vs. 0.2-0.3 in $C$. occidens), and conspicuously upcurved ovipositor (ovipositor only slightly upcurved in C. occidens).

FIELD NOTES. Cosmiocryptus occidens inhabits moist areas with subtropical to prepuna climates (1500 to $2389 \mathrm{~m}$ altitude) in fertile river valleys along much of the Peruvian coast. I have taken it by sweeping dense herbaceous undergrowth along irrigation ditches and also while beating the large composite shrub, Baccharis. Cosmiocryptus and numerous other Hymenoptera often are attracted to Baccharis, where they feed on honeydew produced by the many

'New combination. 


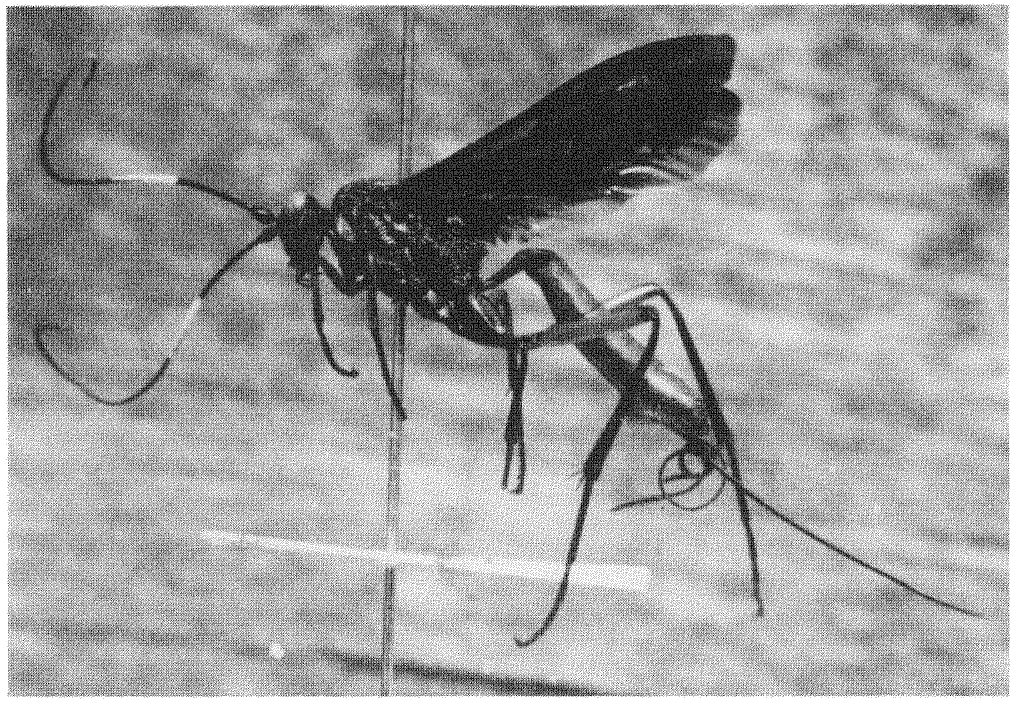

Fig. 2. Cosmiocryptus huascar, ㅇ. Photograph of whole insect in lateral view.

homopterous sap suckers which usually infest this common streamside plant.

SPECIFIC NAME. From the Latin adjective occidens, "west or sunset".

\section{Cosmiocryptus huascar (Porter), new combination}

(Fig. 2, 3, 4).

Trachysphyrus huascar Porter, 1967. Mem. Amer. Ent. Inst. 10: 122-4. Holotype Perú, Largos, 3500 m, 23-III-1960, W. Weyrauch (Tucumán).

I described this species (Porter 1967: 122-24) from 5 females and 1 male collected between $2389 \mathrm{~m}$ and $3500 \mathrm{~m}$ in the Andes of central and western Perú. An additional 4 females now are reported from Matucana, Perú and their analysis permits the following amendments and additions to my original description.

Length of fore wing: 10.5-14.4 mm. First flagellomere: $5.9-6.7$ as long as deep at apex. Malar space: $0.9-1.3$ as long as basal width of mandible. Clypeus: apical margin nearly straight. Temple: $0.5-0.6$ as long as eye in dorsal view. Mesoscutum: notauli reaching up to 

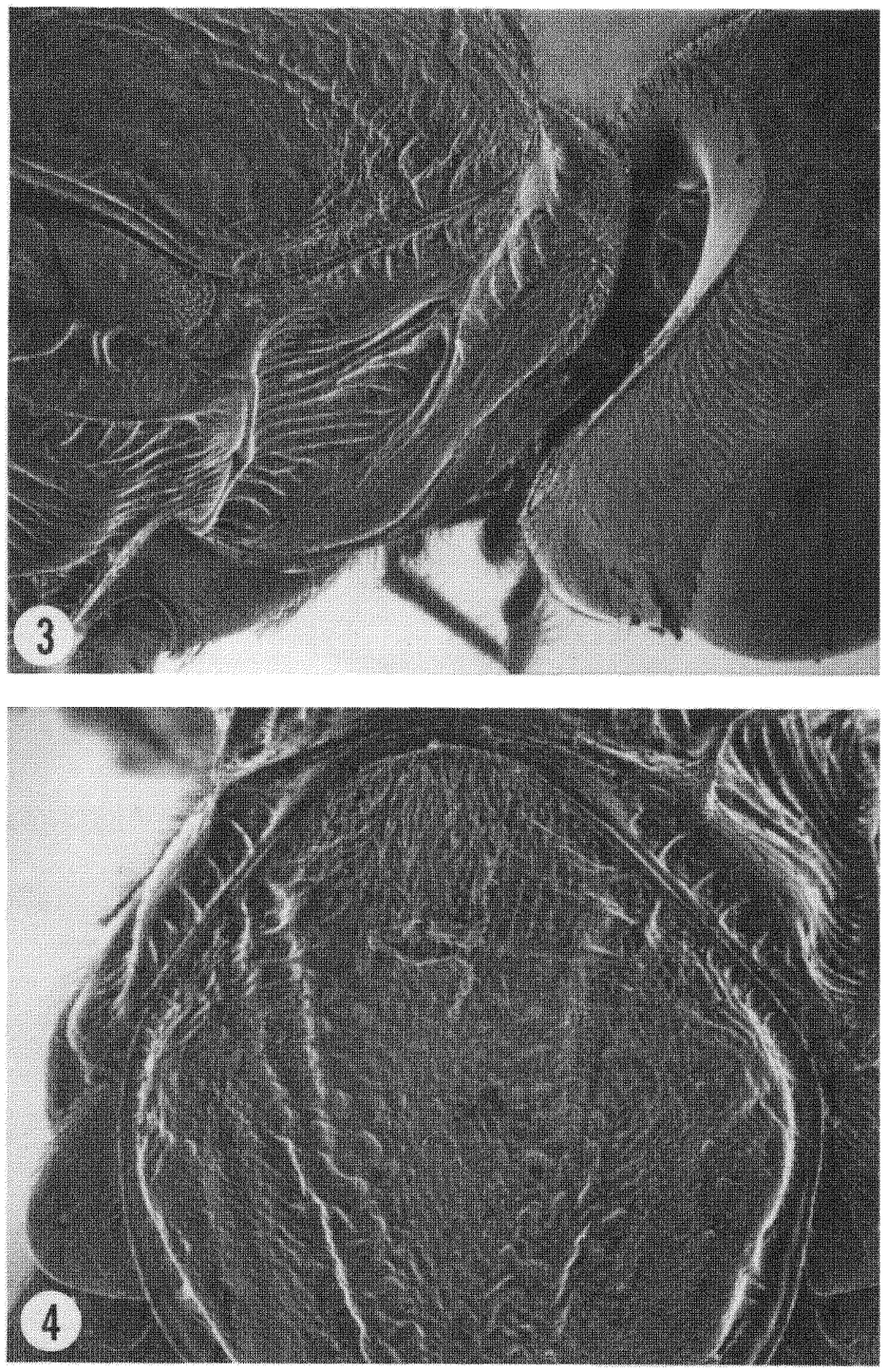

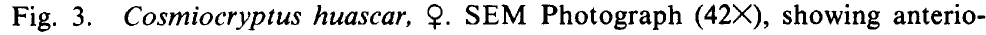
lateral part of thorax.

Fig. 4. Cosmiocryptus huascar, 9 . SEM Photograph (55×), showing pronotum and most of mesoscutum in dorsal view. 
0.8 the length of mesoscutum. Wing venation: ramellus often short but distinct. Propodeum: cristae often very strongly projecting cuneate to ligulate. Ovipositor: notch sometimes obsolete; tip 0.14-0.17 as high at notch as long from notch to apex.

NEW SPECIMENS EXAMINed. 4O: PERÚ, Lima Province, Matucana, 2389 m, 28-30-VI-1974, C. Porter, L. Stange.

VARIATION. Although its range extends from the central Andes at Cuzco and Urubamba to the west Andean slopes near Lima, $C$. huascar shows little variation in the characters studied and offers no phaenotypically aberrant local populations. These facts and its ability to live at altitudes of up to $3500 \mathrm{~m}$ suggest that this species is a recent (i.e. post-Pleistocene) arrival on the upper fringes of the Coastal Desert.

FIELD NOTES. Specimens of $C$. huascar collected at Matucana were found near the Rimac River, as they flew at low altitude over grassy areas or visited Baccharis soaked with homopteran honeydew.

\section{Cosmiocryptus leucetrum Porter, new species}

(Fig. 5)

FEMALE. Color: antenna shining reddish brown, with dusky staining that becomes more prominent apicad; head and mesosoma black with reddish brown on much of mandible, on large clypeal blotch, and on much of scutellum, as well as with a narrow white line on much of frontal orbit and a broader white line that extends along rear of vertical orbit and almost all of hind orbit; 1 st gastric tergite dark red with blackish near base and again faintly on apical margin; 2nd tergite dark red with inconspicuous blackish staining; 3 rd tergite white, except becoming pale brown laterad, and black on basal 0.3; exposed portion of tergites 4-7 white with lateral faint brown suffusion; and tergite 8 black with a little white dorsobasally; legs mostly shining dull red with tibiae and tarsi duller and slightly dusky; wings medium blackish with subdued metallic reflections.

Length of fore wing: $11.3 \mathrm{~mm}$. First flagellomere: 6.3 as long as deep at apex. Clypeus: strongly and a little asymmetrically bluntpyramidal in profile; apical margin gently but definitely convex. Malar space: 1.0 as long as basal width of mandible. Temple: 0.5 as long as eye in dorsal view; receding and only slightly rounded off. Cephalic carinae: sharp and low, occipital carina joining the only 


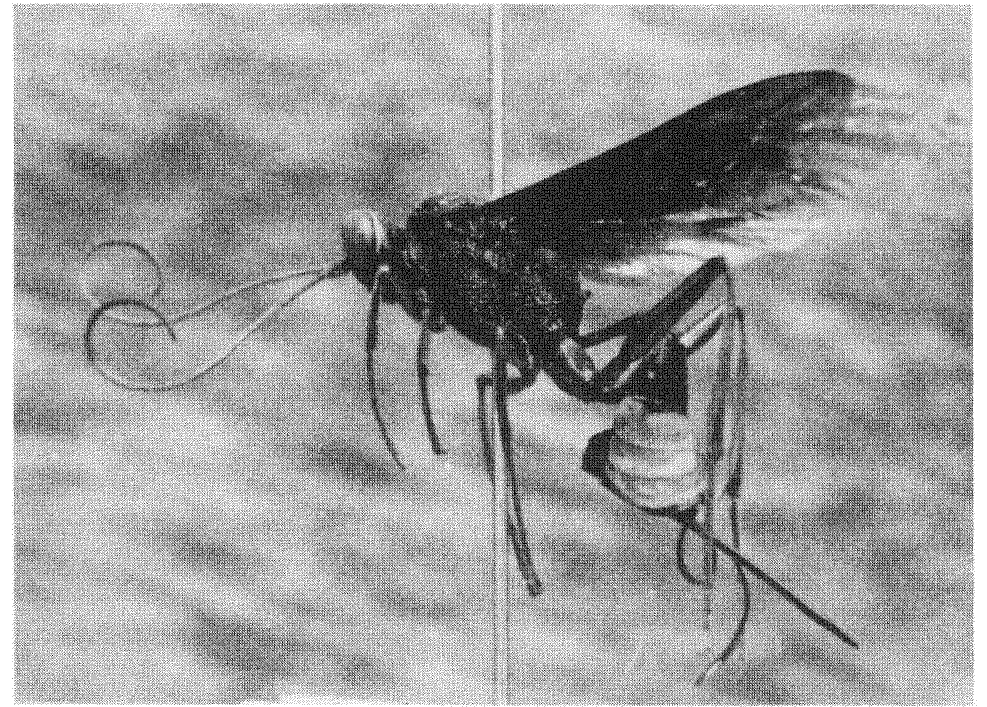

Fig. 5. Cosmiocryptus leucetrum, ㅇ. Holotype. Photograph of entire insect in lateral view.

weakly raised hypostomal carina below. Fore tibia: moderately stout, slightly inflated on median 0.3. Pronotum: submarginal groove broad, shallow, reticulate; epomia sharp in scrobe, practically effaced below scrobe, dorsally terminating in a broad but low and inconspicuous swelling. Mesoscutum: notauli shallow but coarsely reticulate, traceable about 0.8 length of mesoscutum; surface shining with coarse and crowded reticulation and puncto-reticulation; punctures best defined mesad on lobes (especially on lateral lobes) and wrinkling coarsest along notauli and between them rearward. Mesopleuron: speculum swollen, puncto-reticulate peripherally and mostly smooth and shining centrad; surface otherwise with extremely coarse reticulate wrinkling. Wing venation: radial cell 3.7 as long as wide; areolet large, intercubiti moderately converging above, 2nd abscissa of radius 0.8 as long as 1st intercubitus; 2nd recurrent gently inclivous, almost straight; disco-cubitus slightly angled, with a vestigial ramellus; upper part of nervellus 3.0 as long as lower. Propodeum: short and high; faces subequal, the basal arcuately sloping rearward, the apical well differentiated and vertical; spiracle 
2.3 as long as wide; basal trans-carina high but irregular on mid section, obsolete laterad; apical trans-carina obsolete; cristae medium sized, broad, short but well projecting, truncately ligulate; longitudinal carinae obsolete; surface with reticulate wrinkling that is strong to coarse on apical face and on much of basal face between trans-carinae (particularly on a broad arc in position of basal transcarina) and which becomes contrastingly weaker only basad of basal trans-carina. 1st gastric tergite: postpetiole 1.7 as wide apically as long from spiracle to apex; ventro-lateral carinae strong and sharp throughout; dorso-lateral carinae fine but sharp throughout; dorsal carinae represented by the beveled margins of a broad and low median elevation that becomes detectable toward apex of petiole and continues onto much of postpetiole; surface of postpetiole shining, smooth and polished on about apical 0.3 but otherwise with delicate micro-reticulation and with a few tiny punctures that emit short, sparse, inconspicuous setae. 2nd gastric tergite: nearly smooth and conspicuously shining, with delicate micro-reticulation that practically fades out toward apex, as well as with scattered tiny punctures that emit short and very sparse setae. Ovipositor: unusually robust; sheathed portion 0.53 as long as fore wing; nodus low but distinct, with a tiny notch; dorsal valve with a slightly concave taper from notch for about 0.7 the distance to apex and more convexly tapered on apical 0.3 ; ventral valve with strong, oblique ridges on tip; tip 0.30 as high at notch as long from notch to apex.

MALE. Unknown.

TYPe Material. Holotype $\$$ : PERÚ, Lima Province, Cupiche, $10 \mathrm{~km}$ E. Chosica, 25-VI-2-VII-1974, C. Porter, L. Stange. Holotype in Florida State Collection of Arthropods.

RELATIONSHIPS. Cosmiocryptus leucetrum belongs to the Albomarginatus group within its genus as defined by Porter (1967: 150-3). In this subgroup, it seems most closely allied to C. uspallatae Porter, ${ }^{2}$ which occurs in the deserts of western Argentina from Mendoza north to Salta Province (Porter 1967: 167, 1975: 211). Features shared by $C$. leucetrum and $C$. uspallatae include their rather pyramidal clypeus, strongly receding temples, very long 1 st flagellomere (at least 6.0 as long as deep at apex), only finely reticulate 2 nd gastric tergite, relatively long ovipositor (at least 0.50 as

${ }^{2}$ New combination. 
long as fore wing), and stout ovipositor tip ( 0.30 or more as high at notch as long from notch to apex). $C$. leucetrum differs from $C$. uspallatae in its longer malar space (1.0 vs. $0.8-0.9$ as long as basal width of mandible), longer notauli (traceable 0.8 length of mesoscutum vs. 0.3), more coarsely sculptured mesoscutum, extremely coarse mesopleural wrinkling, shorter radial cell (3.7 vs. $4.2-4.3$ as long as wide), longer propodeal spiracle (2.3 as long as wide vs. 1.4-1.7), absence of white on the flagellum, partly red gaster, and dull red (vs. mostly pale orange) legs.

FIELD NOTES. The unique holotype was swept from Baccharis growing on sandy soil within the flood plain of the lower Rimac River.

SPECIFIC NAME. Leucetrum, used here as a noun in apposition, is derived and latinized from the Greek adjective leukos, "white", and the Greek noun êtron, "abdomen".

\section{Cosmiocryptus violaceipennis Cameron}

(Fig. 6, 7)

Cosmiocryptus violaceipennis Cameron, 1902. Trans. Amer. Ent. Soc. 28: 372. Holotype o: Perú, Callao (London).

I redescribed C. violaceipennis (Porter 1967: 218-20) on the basis of 3 females and 1 male collected at Callao (a female cotype), Matucana, and Cañete in the central Coastal Desert and adjacent west Andean slopes. Subsequent collection of 5 more females and 6 new males, obtained not only close to Lima (Rimac Valley, Santa Eulalia Valley) but also in the northern coastal region near Trujillo (Samne), permits further redescription of $C$. violaceipennis.

FEMALE. Color: sometimes blackish on as much as apical 0.5 of hind femur.

Length of fore wing: $7.9-12.1 \mathrm{~mm}$. First flagellomere: $5.5-6.0$ as long as deep at apex. Mesopleuron: swollen area along prepectal carina opposite speculum always conspicuous but invaded to a variable extent by punctures and wrinkles. Wing venation: ramellus strong and elongate; radial cell $3.8-4.3$ as long as wide; 2 nd abscissa of radius $0.6-0.7$ as long as 1 st intercubitus. First gastric tergite: postpetiole $1.5-2.0$ as wide apically as long from spiracle to apex. Ovipositor: sheathed portion $0.40-0.48$ as long as fore wing; tip $0.21-0.28$ as high at notch as long from notch to apex. 


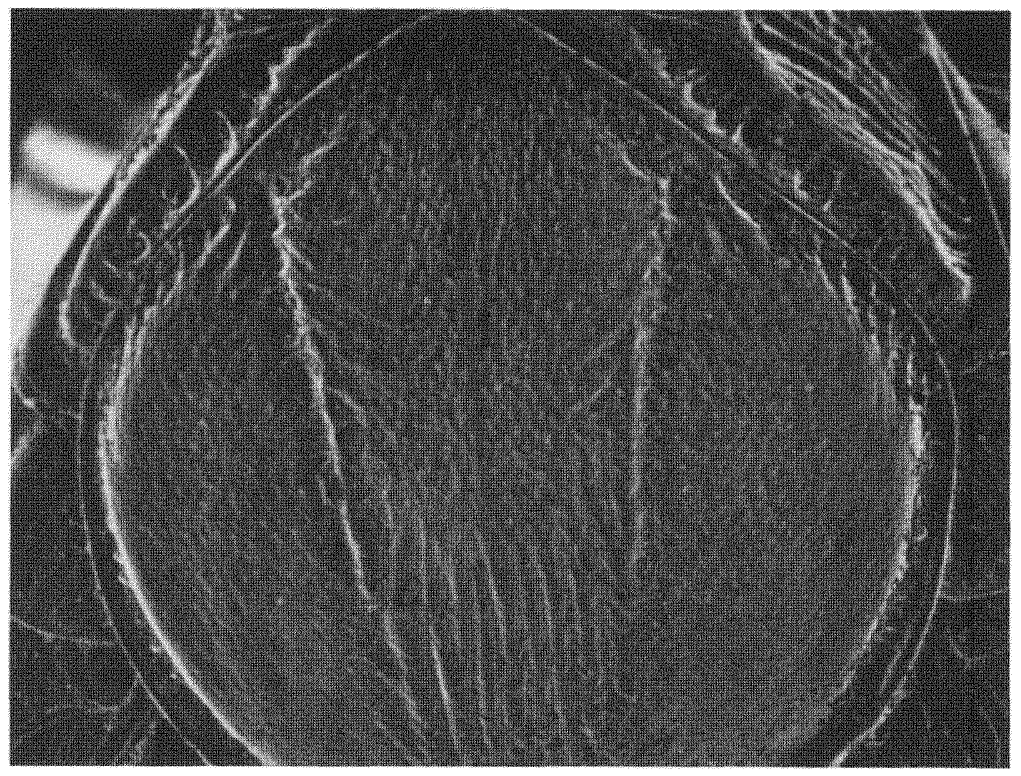

Fig. 6. Cosmiocryptus violaceipennis, ․ SEM Photograph (50X), showing pronotum and most of mesoscutum in dorsal view.

MALE. Color: flagellum with white band beginning on segments 9 or 10 and ending on segments 14,15 , or 16; scape sometimes with a large white spot below or sometimes completely dark; clypeus varying from wholly black to mostly white; sometimes with a pair of white spots mesad on pronotal collar; sometimes a white spot on tegula; scutellum sometimes with a white spot; fore coxae and/or trochanters sometimes extensively white; fore and mid legs sometimes more conspicuously reddish brown than in female; hind tarsomeres 3-4 sometimes partly white.

Length of fore wing: $8.7-10.6 \mathrm{~mm}$. First flagellomere: $3.7-4.5$ as long as deep at apex. Tyloids: at least the 2nd (counting from base of flagellum), and usually the 1st and 3rd also, broadly oval. Temple: $0.6-0.7$ as long as eye in dorsal view. First gastric tergite: postpetiole $0.9-1.4$ as wide apically as long from spiracle to apex.

NEW SPECIMENS EXAMINED. $5 \%$ and 6 $6{ }^{\circ}$ : PERÚ, Lima Province, San Gerónimo, Valle del Río Santa Eulalia, 28-VI-1976, C. 
Porter, C. Calmbacher; Matucana, 2389 m, 28-30-VI-1974, C. Porter, L. Stange, 4-5-VII-1976, C. Porter; La Libertad Province, Samne, 40 km NE Trujillo, ca. 1500 m, 12-17-VII-1975, C. Porter, L. Stange.

RELATIONSHips. This species, along with C. weyrauchi, C. diplatys, C. leptaechma, and C. aricae, forms a distinctive subgroup that is endemic to the Coastal Desert and adjacent Andean slopes (between sealevel and $3400 \mathrm{~m}$ ) in most of Perú and in Tarapacá

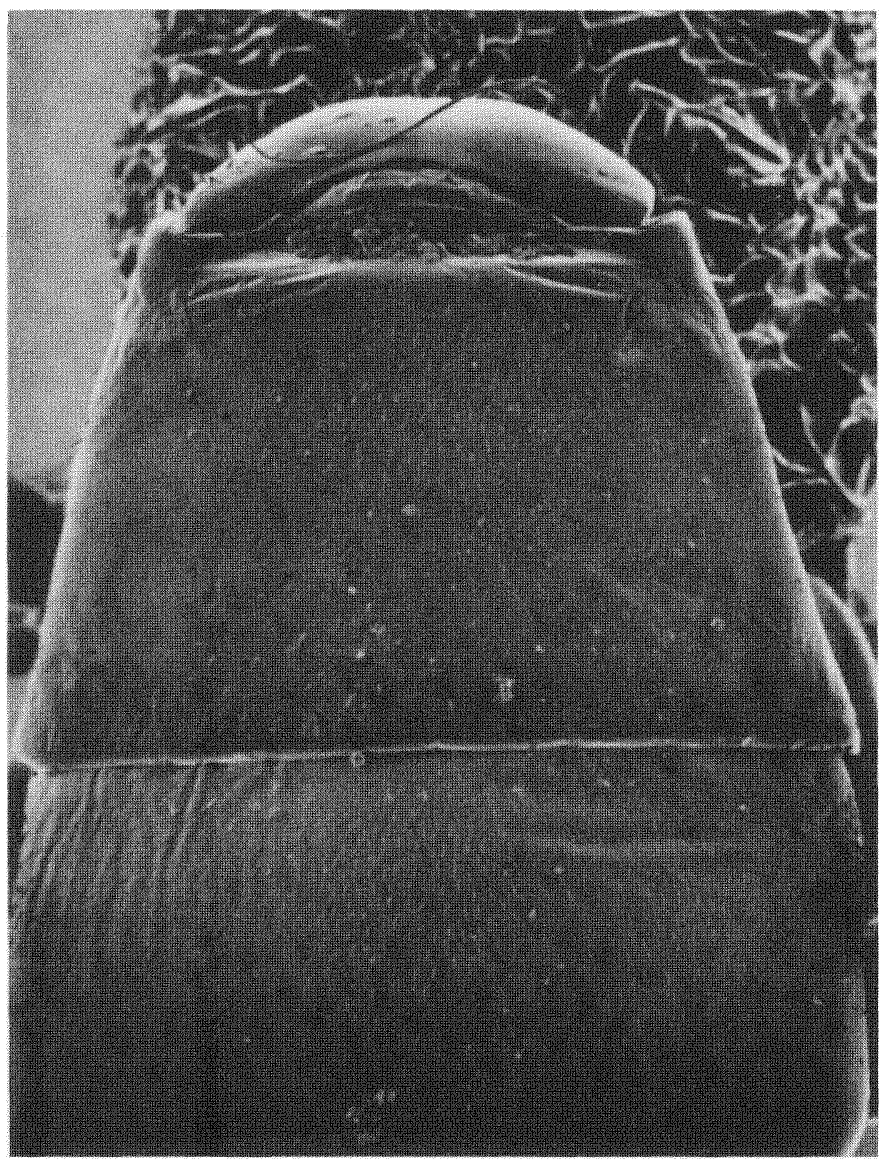

Fig. 7. Cosmiocryptus violaceipennis, ․ SEM Photograph $(110 \times)$, showing rear of propodeum and much of first 3 gastric tergites in dorsal view. 
Province of north Chile. The Violaceipennis group (Porter 1967: 217-18 apparently has no close relatives elsewhere in South America. It thus may have evolved in situ during the last half of the Tertiary, when a rain shadow created by the uplifting Andes allowed development in what is now the Coastal Desert of a thorn scrub vegetation (similar to the Argentine Chaco) and favorable for comparatively dry-adapted ichneumonids, such as Cosmiocryptus and Trachysphyrus.

The ancient progenitor of the Violaceipennis group might well have reached the Coastal Desert from the Argentine and Bolivian Chaco, while the Andes still were low enough to allow easy dispersal between the arid parts of south-central South America and similar communities then developing on the Pacific coast (Solbrig 1976: 38).

FIELD NOTES. Most of my specimens of $C$. violaceipennis were taken while sweeping herbaceous vegetation along rivers or irrigation ditches. The species does not seem to visit Baccharis as often as its relatives.

Host. C. violaceipennis has been reared from "Megalopyge prob. amitina", a megalopygid moth.

\section{Cosmiocryptus diplatys (Porter), new combination}

(Fig. 8, 9, 10).

Trachysphyrus diplatys Porter, 1967. Mem. Amer. Ent. Inst. 10: 222-4. Holotype Perú, Matucana, 2400 m, 23-VI-1955, W. Weyrauch (Tucumán).

C. diplatys was described from a unique female (Porter 1967: 222-24). Subsequent collecting has added 14 females and 50 males to this number, but has not extended the species' range beyond Matucana, Perú. Herewith I give a revised description of the female and characterize the male for the first time.

FEMALE. Color: antenna black with a white annulus on flagellomeres 4 or 5 to 8,9 , or 10 ; mandible usually all black; gaster sometimes with extensive but irregular black staining; often with some red on fore and mid trochantelli and on bases of their femora.

Length of fore wings: $8.1-12.8 \mathrm{~mm}$. Flagellum: long, slender, cylindric; 1st flagellomere 6.2-7.8 as long as deep at apex. Malar space: $0.70-0.90$ as long as basal width of mandible. Temple: $0.6-0.8$ as long as eye in dorsal view; rather strongly receding. Wing venation: radial cell $3.7-4.1$ as long as wide; 2 nd abscissa of radius 

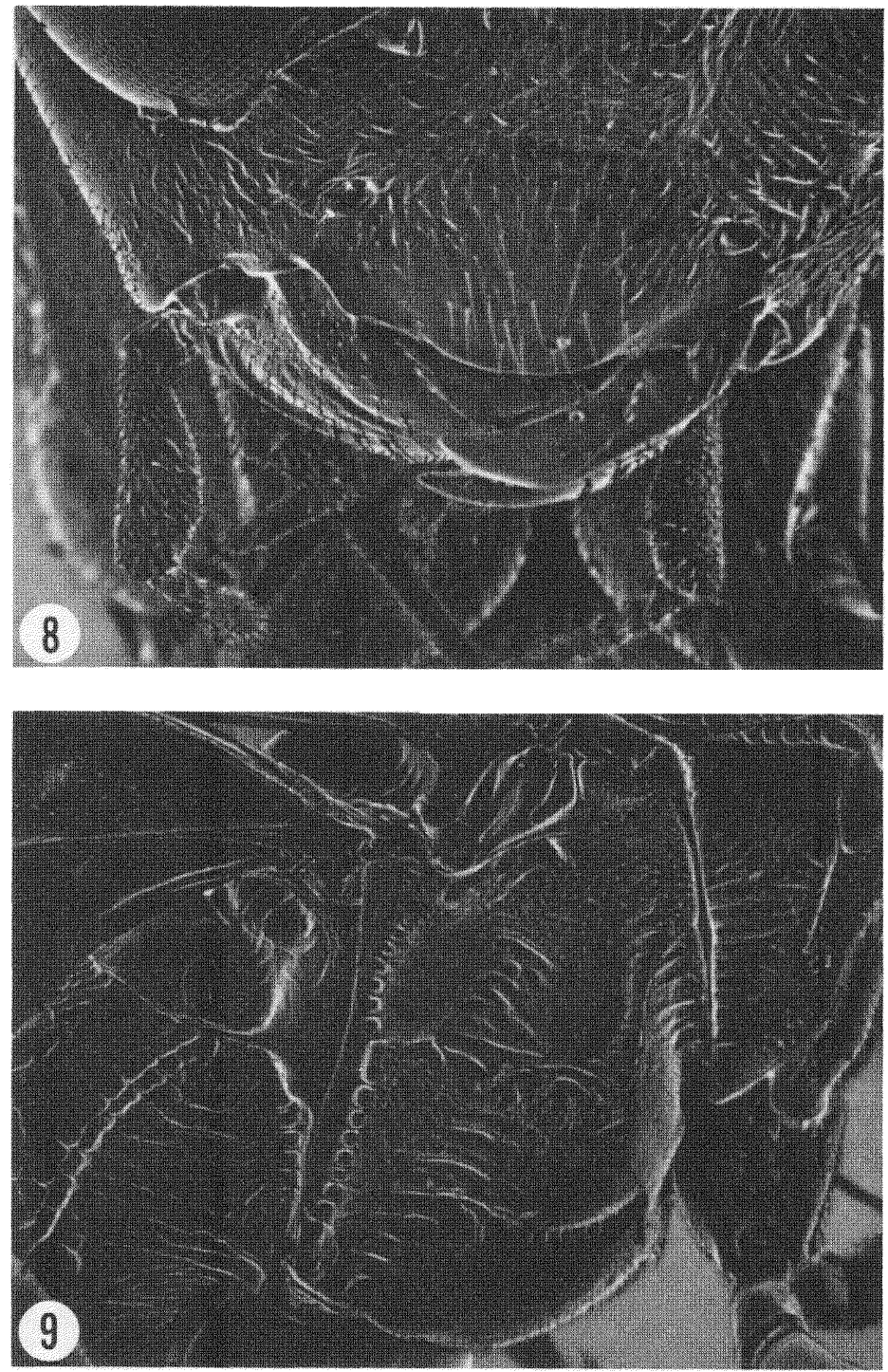

Fig. 8. Cosmiocryptus diplatys, ․ SEM Photograph (110×), showing clypeus and adjacent areas in anterior view.

Fig. 9. Cosmiocryptus diplatys, ㅇ. SEM Photograph $(35 \times)$, showing greater part of mesosoma in lateral view. 


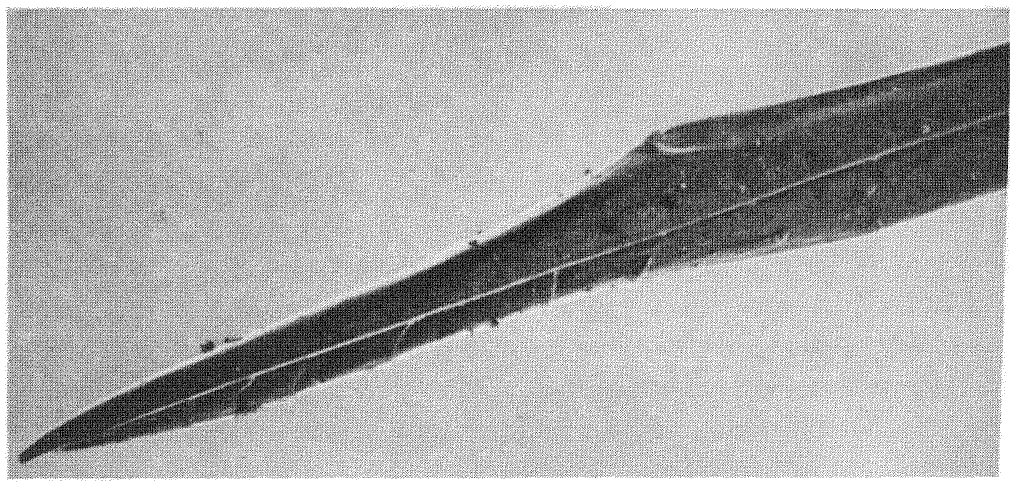

Fig. 10. Cosmiocryptus diplatys, 오. SEM Photograph $(85 \times)$, showing ovipositor tip in lateral view.

0.6-0.7 as long as 1st intercubitus; ramellus sometimes strong. Propodeum: cristae subligulate to subcuneate; wrinkles between the trans-carinae varying from mostly longitudinal to quite irregular. First gastric tergite: postpetiole $1.5-2.3$ as wide apically as long from spiracle to apex. Ovipositor: sheathed portion $0.55-0.63$ as long as fore wing; tip $0.20-0.23$ as high at notch as long from notch to apex.

MALE. Differs from female as follows: Color: white flagellar annulus (often weak below) on segments $7,8,9$, or 10 to 14 or 15 ; white orbital bands broader and more extensive than in female; small white spot on tegula.

Length of fore wing: 7.3-12.0 mm. Flagellum: 1st segment 3.9-5.0 as long as deep at apex; only the 3rd tyloid (counting from base) unusually broad, the rest ovoid to linear. Front: weakly excavated. Clypeus: much as in female, very low in profile with rounded apical margin. Malar space: $0.67-0.80$ as long as basal width of mandible. Temple: $0.7-1.0$ as long as eye in dorsal view; more strongly rounded-off than in female. Mesoscutum: more sparsely punctate than in female, even more shining, sometimes without longitudinal wrinkles mesad between ends of notauli. Propodeum: a little longer and lower in profile than in female; cristae strong and bluntly cuneate; sculpture (also of mesosoma) generally weaker than in female, with more or less extensive smooth areas, often including most of areola. First gastric tergite: postpetiole 1.0-1.3 as wide apically as long from spiracle to apex. Second gastric tergite: with 
abundant tiny, superficial punctures which emit rather long setae that mostly equal or surpass the length of their interspaces.

NEW SPECIMENS EXAMINED. $14 \%$ and 50 $\widehat{0}$ : PERÚ, Lima Province, Matucana, 2389 m, 15-VI-1979, C. Porter, 27-30-VI-1976, C. Porter, C. Calmbacher, 28-30-VI-1974, C. Porter, L. Stange, 4-5VII-1976, C. Porter, C. Calmbacher.

RELATIONShips. Females of $C$. diplatys easily may be distinguished from all sympatric congeners by their conspicuously flattened and otherwise strangely modified ovipositor tip (Fig. 10). The males much resemble those of $C$. violaceipennis but have the mesoscutum more shining and more sparsely punctate and show a different tyloidal conformation.

FIELD NOTES. I have repeatedly found this species common at Matucana toward the upper end of the Rimac Valley in seasonally humid west Andean Prepuna. Most specimens were netted from Baccharis along the main river, its tributaries, and irrigation ditches. They seemed attracted by the homopteran honeydew covering Baccharis foliage. Also they may have been looking for hosts among the larger lepidopterous cocoons (Psychidae, Saturniidae, etc.) suspended from the Baccharis.

This species is known only from Mantucana. However, there are many entomologically unexplored river valleys along the Peruvian coast and $C$. diplatys eventually should appear in some of these.

\section{Cosmiocryptus aricae Porter, new species}

(Fig. 11, 12).

This Cosmiocryptus appears to be a southern vicariant of the central and north Peruvian C. violaceipennis (Cameron). It may be distinguished as follows from its northern relative.

FEMALE. Color: similar to $T$. violaceipennis (black antenna with white band; mostly black head and mesosoma; blackish wings; red gaster) except for the presence of a dull white area above the base of each mandible interiorly.

Length of fore wing: $6.0 \mathrm{~mm}$. First flagellomere: 5.0 as long as deep at apex. Fore tibia: stout and definitely inflated. Mesopleuron: speculum shining but punctured and wrinkled; surface otherwise strongly and irregularly (but not grossly) wrinkled throughout, lacking a polished and swollen area above along prepectal carina facing speculum. Wing venation: radial cell 4.5 as long as wide. 


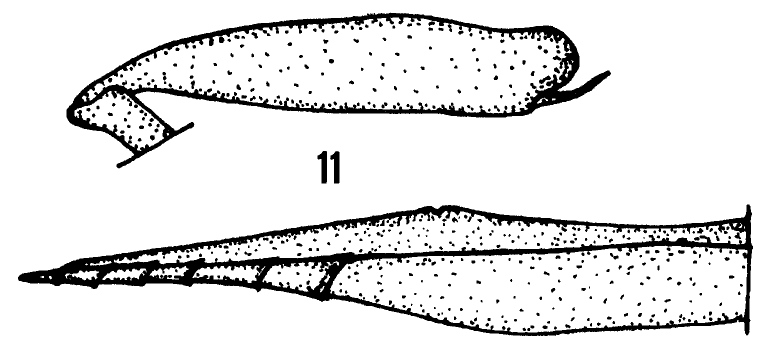

12

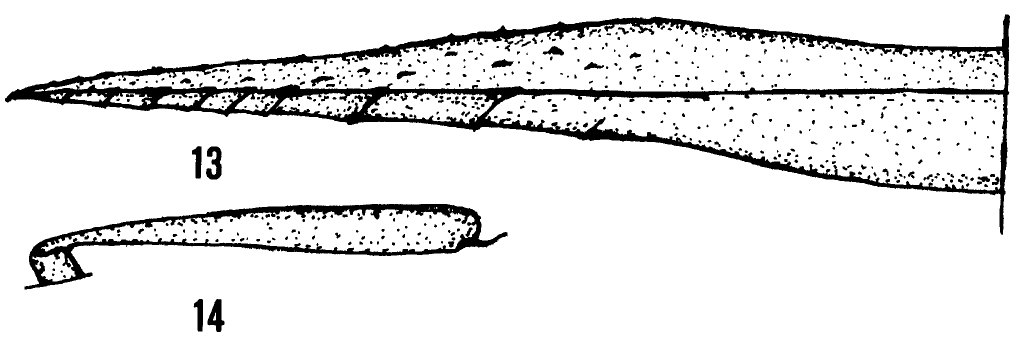

Fig. 11. Cosmiocryptus aricae, 9. Holotype. Fore tibia in lateral view.

Fig. 12. Cosmiocryptus aricae, ․ Holotype. Ovipositor tip in lateral view.

Fig. 13. Cosmiocryptus leptaechma, ․ Holotype. Ovipositor tip in lateral view.

Fig. 14. Cosmiocryptus leptaechma, \&. Holotype. Fore tibia in lateral view.

Propodeum: spiracle 1.4 as long as wide; cristae subligulate, rather low; surface more densely and less grossly reticulo-rugose than in $T$. violaceipennis. First gastric tergite: no flange at base; postpetiole 1.7 as wide apically as long from spiracle to apex. Second gastric tergite: setae sparse and inconspicuous, largely much shorter than the length of their interspaces. Ovipositor: strongly compressed; sheathed portion 0.5 as long as fore wing; nodus rather prominently elevated and with a sharp but tiny notch; dorsal valve with a fairly strong, direct taper between notch and apex.

MALE. Unknown.

TYPE Material. Holotype \&: CHILE, Tarapacá Province, Chapiquiña, 3170 m, I-1977, in Malaise Trap, C. Porter. Holotype in Florida State Collection of Arthropods. 
RELATIONSHIPS. This species shows great superficial resemblance to $C$. violaceipennis but may be distinguished by the features given in the preceding diagnosis and emphasized in the key. The distinctive ovipositor tip of $C$. aricae suggests that its host preferences may differ from those of other sympatric Violaceipennis group species.

FIELD NOTES. The Malaise Trap used at Chapiquiña, a Puna locality more than $3000 \mathrm{~m}$ above Arica, was placed across a small stream bordered by dense, tall bunch grass and, more distantly, by alfalfa fields and Eucalyptus plantations.

SPECIFIC NAME. Aricae is a latinized genitive singular derived from the Chilean city of Arica.

\section{Cosmiocryptus leptaechma Porter, new species}

(Fig. 13, 14).

FEMALE. Color: antenna black with a white band above on flagellomeres 3-10; head and mesosoma black; a white line briefly on facial orbit opposite antennal socket, a short white line on orbit at top of eye, and a white line on about median 0.4 of hind orbit; fore and mid legs black with faint reddish brown staining, especially apicad on femora; hind leg with coxa, trochanter, trochantellus, and most of femur red; weakly blackish on apical 0.8 of hind femur and uniformly black on tibia and tarsus; gaster red; wings blackish with metallic blue and purple reflections.

Length of fore wing: $9.4 \mathrm{~mm}$. Flagellum: long, slender, cylindric; 1st flagellomere 6.0 as long as deep at apex. Front: moderately excavated. Clypeus: gently and almost symmetrically convex in profile; apical margin gently convex. Malar space: 0.8 as long as basal width of mandible. Temple: 0.4 as long as eye in dorsal view; strongly receding and gently convex. Fore tibia: stout but not at all inflated. Wing venation: radial cell 3.6 as long as wide. Propodeum: spiracle 2.0 as long as wide; propodeal surface as grossly but less reticulately or irregularly wrinkled than in violaceipennis. First gastric tergite: postpetiole 1.5 as wide at apex as long from spiracle to apex. Second gastric tergite: strongly shining with faint but palpable micro-reticulation or shagreening (more polished than in $T$. violaceipennis); punctures very sparse and faint, their setae much more widely spaced than the lengths of the interspaces. Ovipositor: sheathed portion 0.5 as long as fore wing; straight, rather slender, strongly compressed; nodus very low, weakly defined, with a small 

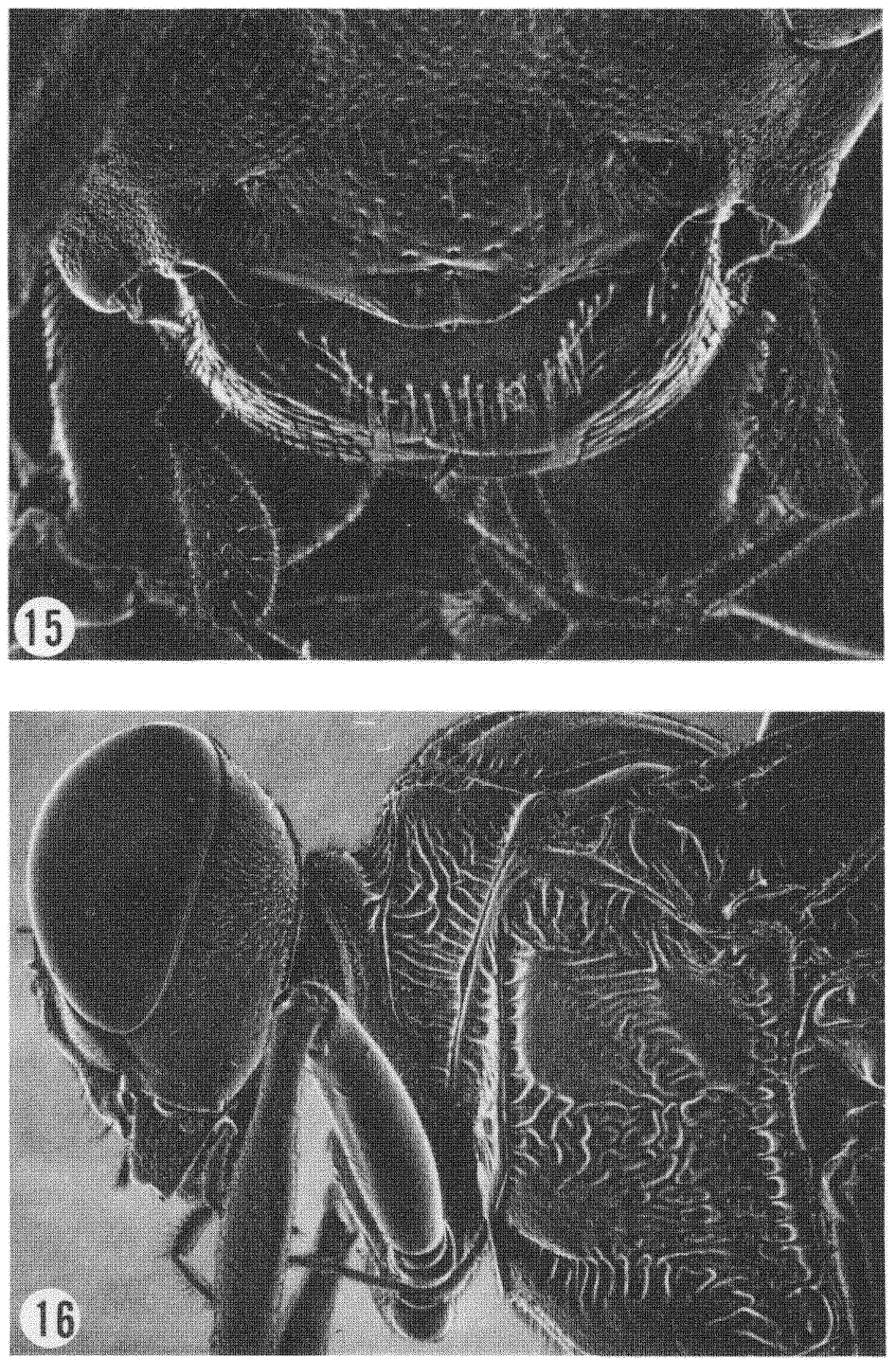

Fig. 15. Cosmiocryptus weyrauchi, + . SEM Photograph $(70 \times)$, showing head and adjacent areas in anterior view.

Fig. 16. Cosmiocryptus weyrauchi, ㅇ. SEM Photograph $(25 \times)$, showing head, prothorax, and mesothorax in lateral view. 
and shallow notch; dorsal valve with sparse but conspicuous tiny tubercles and with a very gradual and nearly direct taper between notch and apex; tip 0.16 as high at notch as long from notch to apex.

MALE. Unknown.

TYPe Material. Holotype \&: PERÚ. Lima Province, Matucana, 2389 m, 28-30-VI-1977, C. Porter, L. Stange. Holotype in Florida State Collection of Arthropods.

RELATIONSHIPS. This species is closely related to $C$. violaceipennis and C. aricae. The very slender, microtuberculate ovipositor tip and uniflated fore tibia constitute the best diagnostic features of $C$. leptaechma. Also distinctive are its low and almost symmetrically convex clypeal profile and strongly shining 2 nd gastric tergite with only faint micro-reticulation and widely scattered setae.

FIELD NOTES. Cosmiocryptus leptaechma can not be distinguished at sight from other members of the Violaceipennis species group. I thus offer no specific information about the circumstances of its capture at Matucana, Perú.

SPECIFIC NAME. Leptaechma, used here as a noun in apposition, is derived and latinized from the Greek adjective leptos, "delicate", and the Greek noun aichme, "spear point".

\section{Cosmiocryptus weyrauchi (Porter), new combination}

(Fig. 15, 16, 17, 18, 19).

Trachysphyrus weyrauchi Porter, 1967. Mem. Amer. Ent. Inst. 10: 220-2. Holotype

ㅇ: Perú, "Huarochiri”, 3400 m, 5-VIII-1961, W. Weyrauch (Tucumán).

In 1967 (Porter: 220-22) I described T. weyrauchi from 1 Peruvian female and 2 males collected in Tarapacá Province of north Chile. More recent fieldwork has added 6 females and 16 males, permitting some additions and modifications with regard to the original diagnosis.

FEMALE. Color: white flagellar annulus sometimes beginning on 1st segment; gaster in a few specimens with extensive black staining (but always with conspicuous red areas); sometimes with at least a little red on coxae, trochanters, and femora basally; hind leg often wholly or almost wholly black.

Length of fore wing: $9.5-11.0 \mathrm{~mm}$. First flagellomere: $5.0-6.2$ as long as deep at apex. Malar space: $0.86-0.90$ as long as basal width 

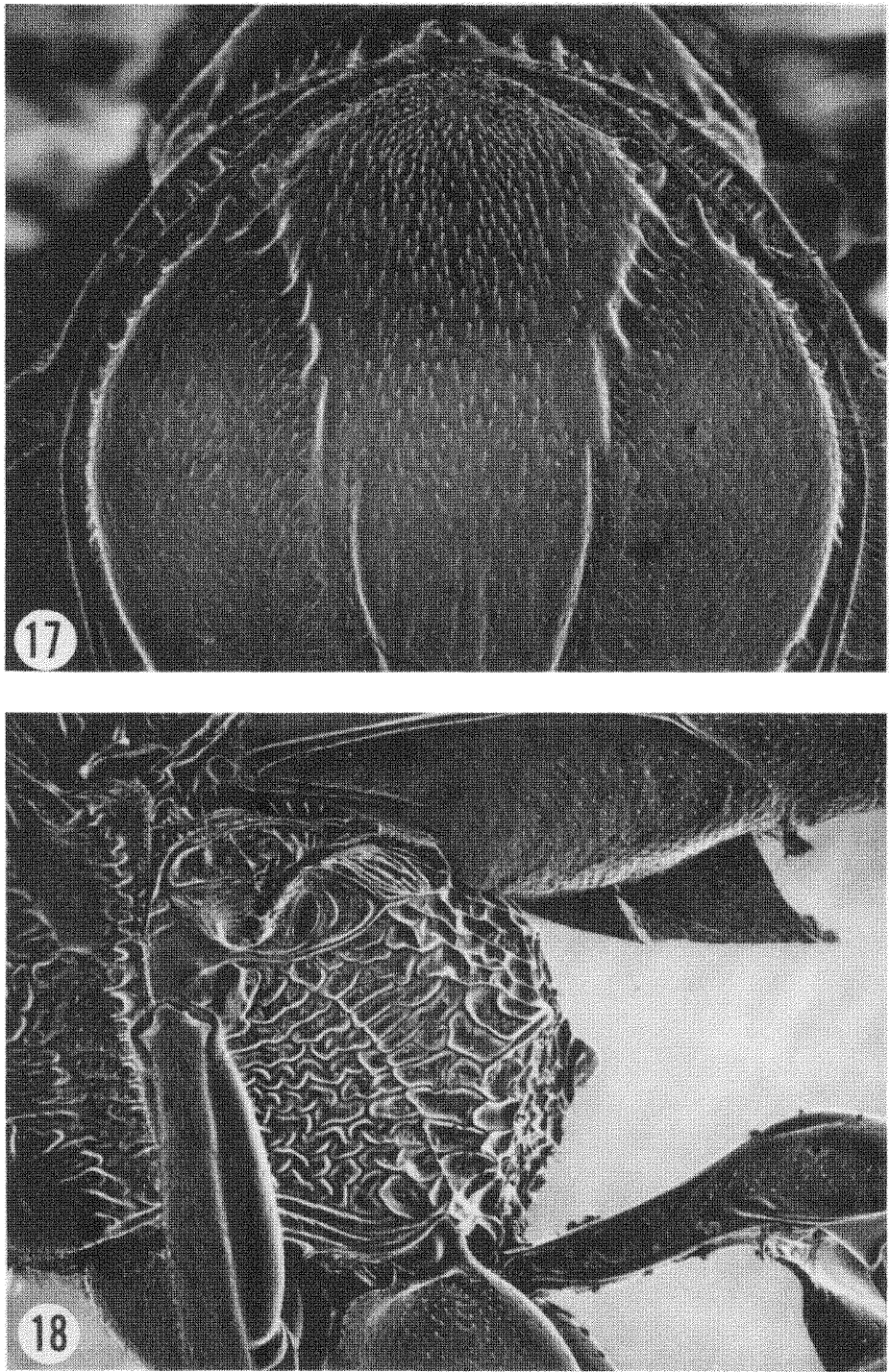

Fig. 17. Cosmiocryptus weyrauchi, ․ SEM Photograph $(55 \times)$, showing pronotum and most of mesoscutum in dorsal view.

Fig. 18. Cosmiocryptus weyrauchi, . . SEM Photograph $(45 \times)$, showing rear of mesopleuron, propodeum, and most of first gastric tergite in lateral view. 
of mandible. Temple: $0.5-0.6$ as long as eye in dorsal view. Mesopleuron: often smooth and polished even in lower front quadrant. Wing venation: radial cell $3.8-4.4$ as long as wide. Propodeum: spiracle $2.2-2.3$ as long as wide. First gastric tergite: postpetiole $1.7-2.0$ as wide apically as long from spiracle to apex. Ovipositor: sheathed portion $0.5-0.6$ as long as fore wing; nodus often rather prominent; tip $0.23-0.30$ as high at notch as long from notch to apex.

MALE. Color: white flagellar annulus on segments $5,6,7,8$ or 9 to 13,14 , or 15 ; mid coxa occasionally marked with red.

Length of fore wing: 4.8-9.4 mm. Flagellum: tyloids all much longer than broad, the 1st 3 linear (counting from base of antenna); 1st flagellomere 2.6-3.2 as long as deep at apex. Malar space: $0.70-0.84$ as long as basal width of mandible. Temple: $0.6-0.8$ as long as eye in dorsal view. Mesoscutum: notauli traceable up to 0.6 length of mesoscutum. Mesopleuron: in small specimens sometimes almost wholly smooth and polished. Propodeum: surface in small specimens often extensively smooth and shining; cristae often as strong as in female. First gastric tergite: postpetiole 1.3-1.8 as wide at apex as long from spiracle to apex. Second gastric tergite: setae generally shorter than the length of their interspaces, but in 1 specimen mostly approaching interstitial length.

NEW SPECIMENS EXAMINED. 69 and 160: PERÚ, Lima Province, Matucana, 2389 m, 28-30-VI-1974, C. Porter, L. Stange; CHILE, Tarapacá Province, Belén, 3170 m, 18-19-VII-1976, C. Porter, C. Calmbacher, H. Vargas; Chapiquiña, 3170 m, I-1977, Malaise Trap, C. Porter, IX-1977, Malaise Trap, C. Porter, 5-6-VII1977, C. Porter, G. Díaz, 17-20-VII-1976, 3370 m, C. Porter, C. Calmbacher, 21-VII-1977, C. Porter, 3-VIII-1975, C. Porter, A. Matta; Socoroma, 3000 m, 28-VI-1977, C. Porter, VII-1977, Malaise Trap, C. Porter, 7-VII-1977, C. Porter, G. Díaz.

RELATIONSHIPS. The bituberculate clypeus, usually rather sparse setae on the 2nd gastric tergite, and uniformly elongate tyloids distinguish this conspicuous and somewhat aberrant species from all other members of its subgroup.

FIELD NOTES. Cosmiocryptus weyrauchi frequents tall vegetation, such as Baccharis and bunch grass, but also may be found on or near the ground among various grasses and forbes, including alfalfa and oregano. 


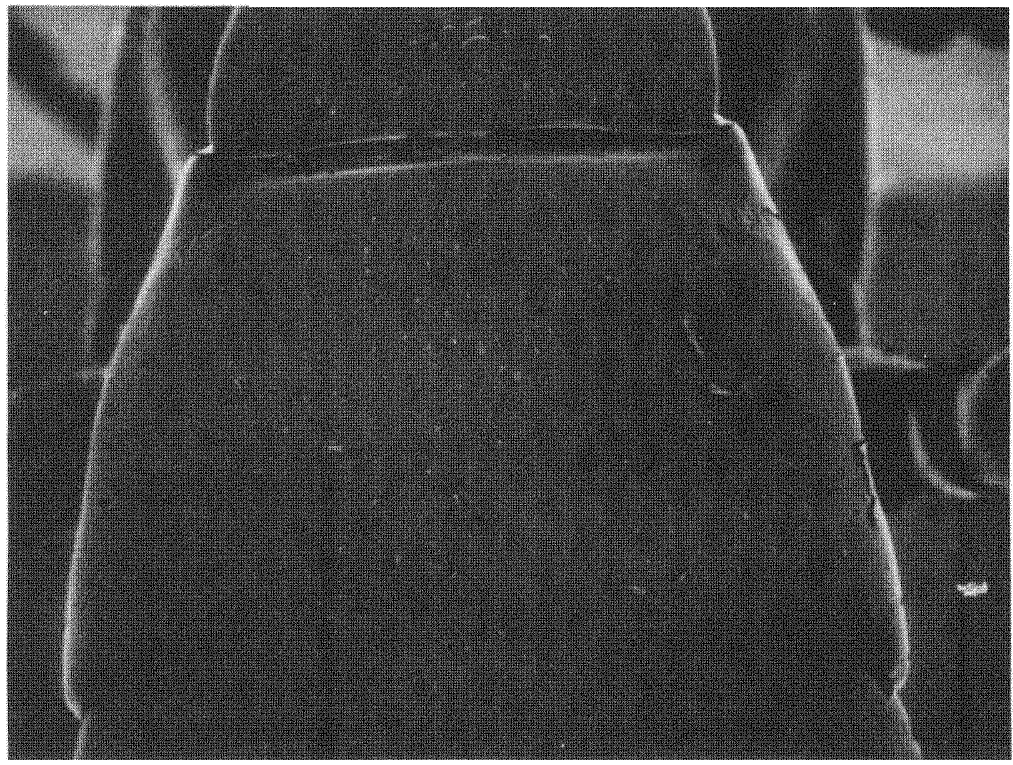

Fig. 19. Cosmiocryptus weyrauchi, . . SEM Photograph (45X), showing second gastric tergite and adjoining areas in dorsal view.

\section{ACKNOWLEDGMENTS}

This work was accomplished under my current U.S. National Science Foundation Grant (BSR-8313444) and in part supported by previous grants from the same agency (DEB-75-22426, GB-6925). Grants for field research in South America awarded in 1973, '74, '75, '79 and ' 81 by the National Geographic Society's Committee for Research and Exploration helped enormously in amassing specimens and habitat data. Additional and crucial support came from Fordham University Faculty Fellowships awarded for the Spring Semester of 1980 and the Fall Term of 1984.

As Research Associate of the Florida State Collection of Arthropods (Florida Department of Agriculture at Gainesville), I received continual support during these studies. I am especially grateful to Dr. Howard V. Weems, Jr., Dr. Lionel A. Stange, and Mr. Harold A. Denmark of that institution, for furnishing research supplies, arranging and assisting on field trips, and for other aid. 
Much of the fieldwork for this study was done in north Chile thanks to extraordinarily selfless and cordial cooperation from the Universidad del Norte at Arica, among whose personnel I especially thank Dr. Raúl Cortés P., Ing. Alfonso Matta, Ing. Héctor Vargas, Tec. Nelson Hichins O., and Aux. Gerardo Díaz P.

Mr. Jaime Zung of Fordham University prepared the Scanning Electron Microscope photographs. I am appreciative of his patience in obtaining excellent pictures without the standard gold coating. Mr. Zung worked under Dr. E. Ruth Witkus, Professor and former chairman of Fordham Biology.

\section{SUMMARY}

The mesostenine genus Cosmiocryptus ranges from Ecuador to Tierra del Fuego in Andean, temperate, xeric, subtropical, marginally tropical, and Neantarctic biomes. It has 8 species in the Coastal Desert, of which 7 (C. violaceipennis, $C$. weyrauchi, $C$. diplatys, $C$. aricae, C. leptaechma, C. leucetrum, and C. occidens) seem to be endemic, while the eighth, $C$. huascar, ranges across the Peruvian Andes as far as Cuzco. As here characterized, Cosmiocryptus includes mesostenine ichneumonids related to Trachysphyrus but with the axillus vein almost appressed to the anal margin of the hind wing. It is also related to Chromocryptus but usually lacks large punctures on the 2nd gastric tergite and a baso-lateral expansion on the 1st tergite. Herein described are 4 new species of Cosmiocryptus: $C$. occidens and $C$. leucetrum from north-central Perú plus $C$. aricae and C. leptaechma from north Chile.

\section{Literature Cited}

Porter, C. 1967. A revision of the South American species of Trachysphyrus. Mem. Amer. Ent. Inst. 10: 1-368.

Porter, C. 1979. Ichneumonidae de Tarapacá. I. Subfamilia Ephialtinae (Ichneumonidae). Idesia: Departamento de Agricultura de la Universidad del NorteArica 5: $157-87$.

Solbrig, O. 1976. The origin and floristic affinities of the South American temperate deciduous and semidesert regions. In D. Goodall (ed.), Evolution of Desert Biota, pp. 7-49. Univ. of Texas Press, Austin.

Townes, H. K. 1969. Genera of Ichneumonidae, Part 2: Gelinae. Mem. Amer. Ent. Inst. 12: 1-537. 

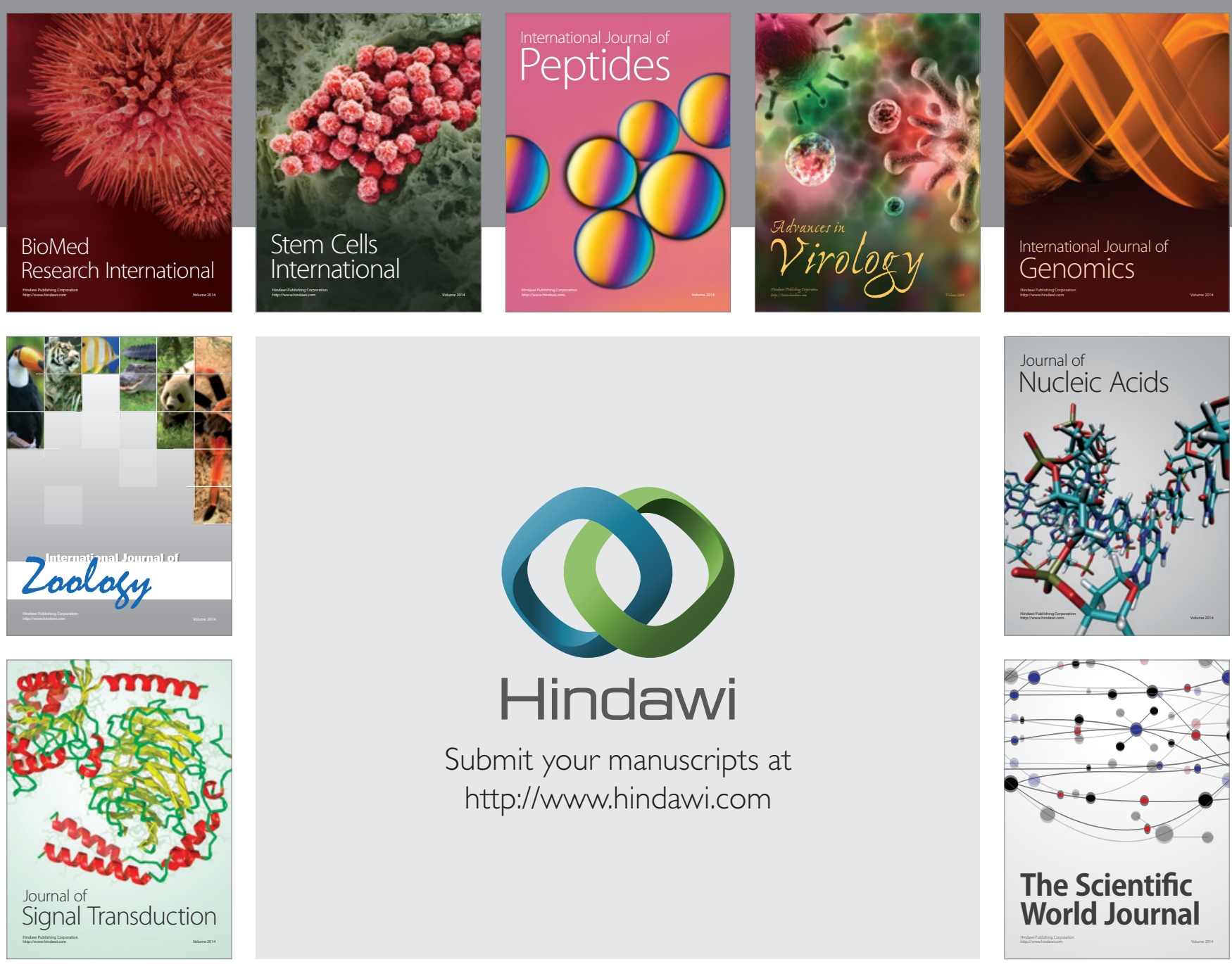

Submit your manuscripts at

http://www.hindawi.com
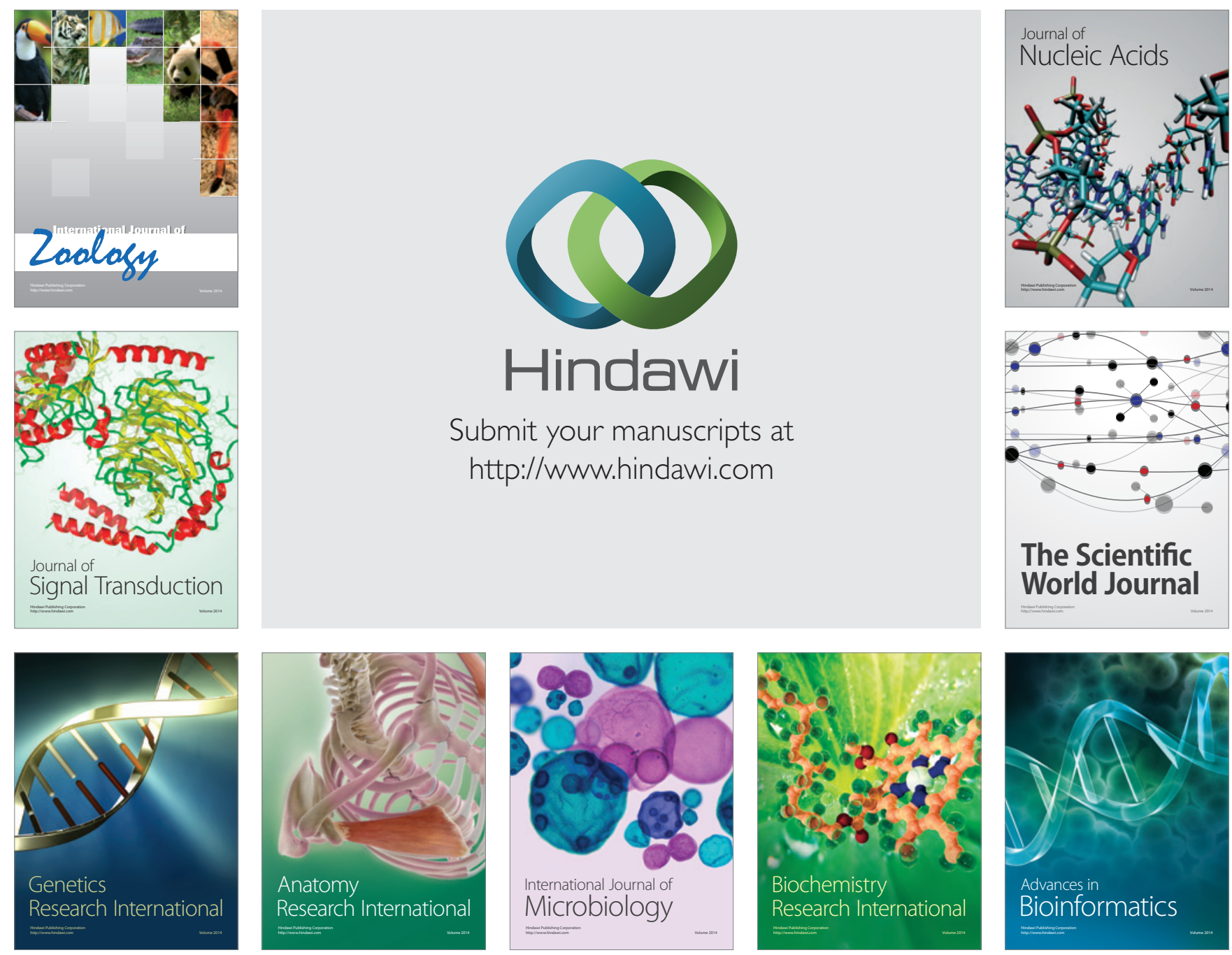

The Scientific World Journal
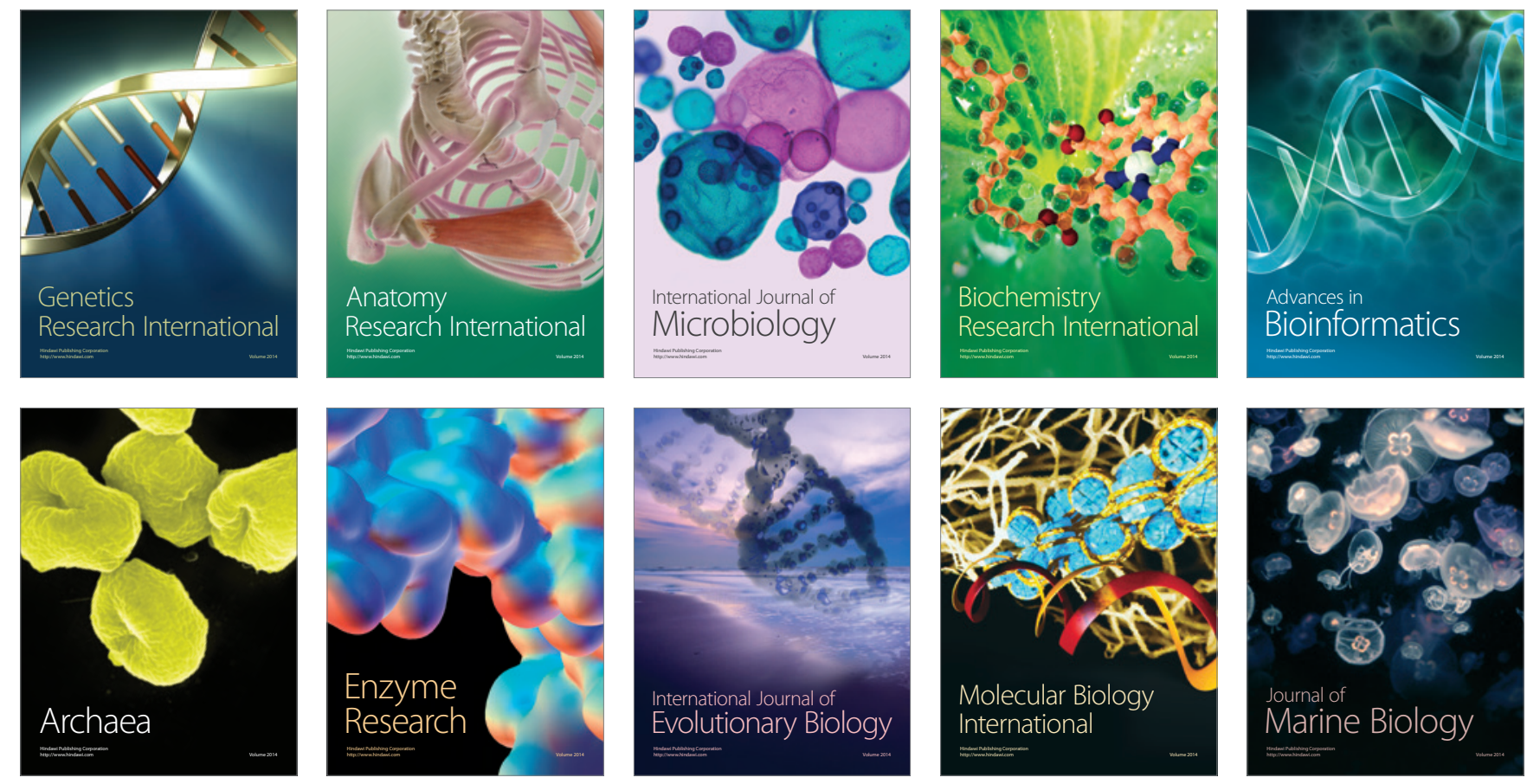